DOI: $10.14451 / 1.181 .9$

\title{
ГОСУДАРСТВЕННЫЙ БЮДЖЕТ И МАКРОЭКОНОМИЧЕСКИЕ ДИСБАЛАНСЫ РАЗВИТИЯ ИНДИИ
}

\author{
(c) 2019 Белостоцкий Алексей Александрович \\ кандидат экономических наук, доцент \\ Курский государственный университет, Россия, Курск \\ E-mail: a.a.belostotskiy@gmail.com
}

В статье проведен анализ макроэкономических показателей, состояния национальной экономики и государственного бюджета Индии в условиях макроэкономического дисбаланса и экономического роста отдельных стран.

Ключевые слова: национальная экономика, государственный бюджет, ВВП государственный долг, банковский сектор, дефицит бюджета.

Экономика Индии развивается в открытую рыночную экономику, хотя следы прежней политики остаются, методы, направленные на либерализацию экономики, приватизацию государственных предприятий, и снижение управления по вопросам внешней торговли и инвестиций, начались в начале 1990-х годов, и их целью является ускорить рост экономики Индии; рост составлял чуть меньше 7\% в период с 1997 по 2011 года. Экономический рост Индии начал замедляться в 2011 году из-за спада инвестиций, вызванным высокими процентными ставками, растущей инфляцией, пессимизмом инвесторов по поводу обещания правительства проводить дальнейшие экономические реформы, и из-за глобальной ситуации. В конце 2012 года правительство Индии объявило о дополнительных реформах и мерах по сокращению дефицита, включая разрешение инвесторам более высоких уровней принимать участие в прямых инвестициях в экономику Индии. Прогноз для Индии для долгосрочного роста умеренно положительный из-за молодого населения и соответствующего низкого коэффициента зависимости, здоровых норм сбережений и инвестиций, и повышения интеграции в глобальную экономику. Экономический рост в 2013 году уменьшился за последнее десятилетие, так как экономические руководители Индии не смогли улучшить широкий бюджетный дефицит страны и дефицит текущего счета.

Рост макроэкономических дисбалансов в Индии и улучшающиеся экономические условия в западных странах привели к тому, что инвесторы перенаправили капитал из Индии, что вызвало резкую девальвацию рупии. Однако оценка Индии инвесторами улучшилась в начале 2014 года, благодаря сокращению дефицита текущего счета, и ожиданию экономических реформ, что привело к всплеску входящих потоков капитала и стабилизации рупии [2].

Более чем половина личных сбережений граждан инвестированы в физические активы, такие как земля, здания, рогатый скот, и золото. На долю банков государственного сектора приходится более чем $75 \%$ общей стоимости банковского имущества в стране, а на долю частных и иностранных банков - $18,2 \%$ и $6,5 \%$ соответственно. В период либерализации экономики правительство провело существенные банковские реформы. В то время как некоторые из них касаются национализированных банков, слияния компаний, уменьшения вмешательства государства в банковскую деятельности и увеличения доходности и конкурентоспособности, другие реформы послужили открытию частных и иностранных банков и страховых компаний [3].

Валовой внутренний продукт в Индии в 2016 году составил 2263,52 млрд. долл. Значение ВВП Индии составляет 3,65 процента мировой экономики. ВВП в Индии составил в среднем 509,73 млрд. долл. с 1960 по 2016 год, достигнув рекордного уровня в 2263,52 млрд. долл. в 2016 году и рекордного минимума в 36,54 млрд. долл. в 1960 году. Динамика валового внутреннего продукта Индии отражена на рисунке 1.

Учитывая, что рост ВВП в последние годы составлял, в среднем, 5,5\%, можно говорить о том, что экономика росла стабильно, но не совсем равномерно являясь одной из самых быстро развивающихся и конкурентоспособных экономик мира. Одна из существенных проблем это 


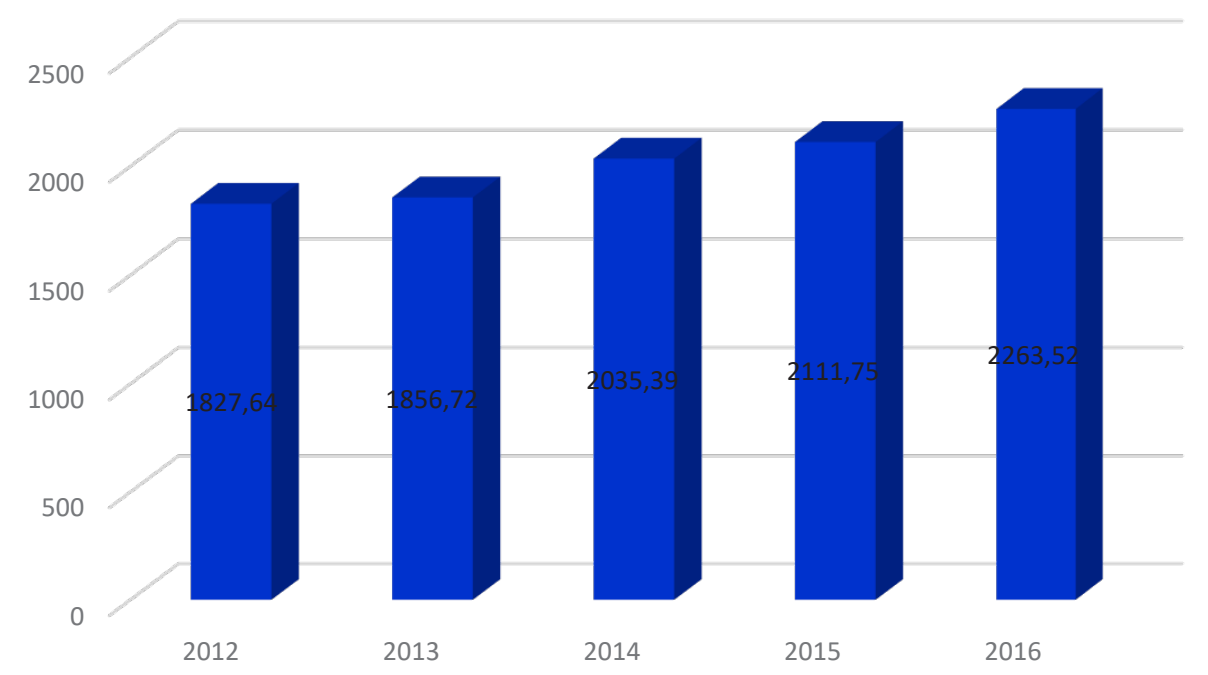

Рисунок 1. Динамика валового внутреннего продукта Индии, млрд. долл. США

скачкообразный рост государственного долга, который сократился в 2000-х года до 43,6 млрд. долл. США, но затем последовал рост до 227,7 млрд. долл. США В 2011 году.

Мобилизация налоговых и неналоговых доходов в бюджет государства осуществляется в соответствии с федеральным законодательством, в соответствии с которым закреплен список действующих налогов, а регулирующую функцию осуществляет финансовая комиссия на федеральном уровне и финансовые комиссии штатов.

На федеральном уровне доходы бюджета формируют: налог на физических лиц, на прибыль корпораций, акцизы и таможенные пошлины, а на уровне штатов, налог на землю, с продаж, акцизы на фармацевтическую и спиртосодержащую продукцию, а также гербовые сборы

Из 85\% поступлений от подоходного налога и $45 \%$ поступлений от федеральных акцизов формируется единый фонд трансфертов, средства которого распределяются следующим образом:

- 20\% фонда распределяется пропорционально населению штатов;

- $60 \%$ - пропорционально отклонению бюджетной обеспеченности данного штата от бюджетной обеспеченности самого «богатого» штата;

- $5 \%$ распределяется пропорционально территории штатов;

- $5 \%$ распределяется пропорционально обеспеченности штатов социальной инфраструктурой, которая измеряется с помощью индекса, рассчитываемого экспертной группой;
- $10 \%$ - пропорционально коэффициенту налоговых усилий, умноженному на население штата [5].

Доходы государственного бюджета Индии выросли до 7673,27 млрд. индийских рупий (IND) в октябре 2017, с 6502,49 млрд. IND в сентябре 2017 года. Доходы бюджета в период с 1997 по 2017 год составили в среднем 2618,07 млрд. IND, достигнув рекордного минимума 14397,87 млн. IND в марте 2017 года и рекордного минимума из 0,82 млн. долл. США в апреле 1999 года. Расходы государственного бюджета Индии увеличились до 3962,84 млн. индийских рупий (IND) в третьем квартале 2017 года с 3910,80 млн. IND. Во втором квартале 2017 года. Государственные расходы в Индии в среднем составили 1932,98 млн. IND. C 2004 по 2017 год, достигнув рекордного уровня в 3962,84 млн. IND в третьем квартале 2017 года и рекордным минимумом в 735,82 млрд. IND. во втором квартале 2004 года. Данные государственного бюджета Индии отражены на рисунке 2.

Государство стремится сократить бюджетный дефицит до 3,2 процента ВВП в текущем финансовом году, который заканчивается в марте, по сравнению с 3,5 процента в предыдущем году [4].

Государственный долг Индии составляет 69,5\% от ВВП в 2016 году. При этом в период с 1991 по 2016 год средний уровень госдолга составлял 73,42\% достигнув своего минимального значения в 66\% в 1996 году и максимального уровня в 84,2\% в 2003 году. Динамика уровня государственного долга Индии представлена на рисунке 3. 


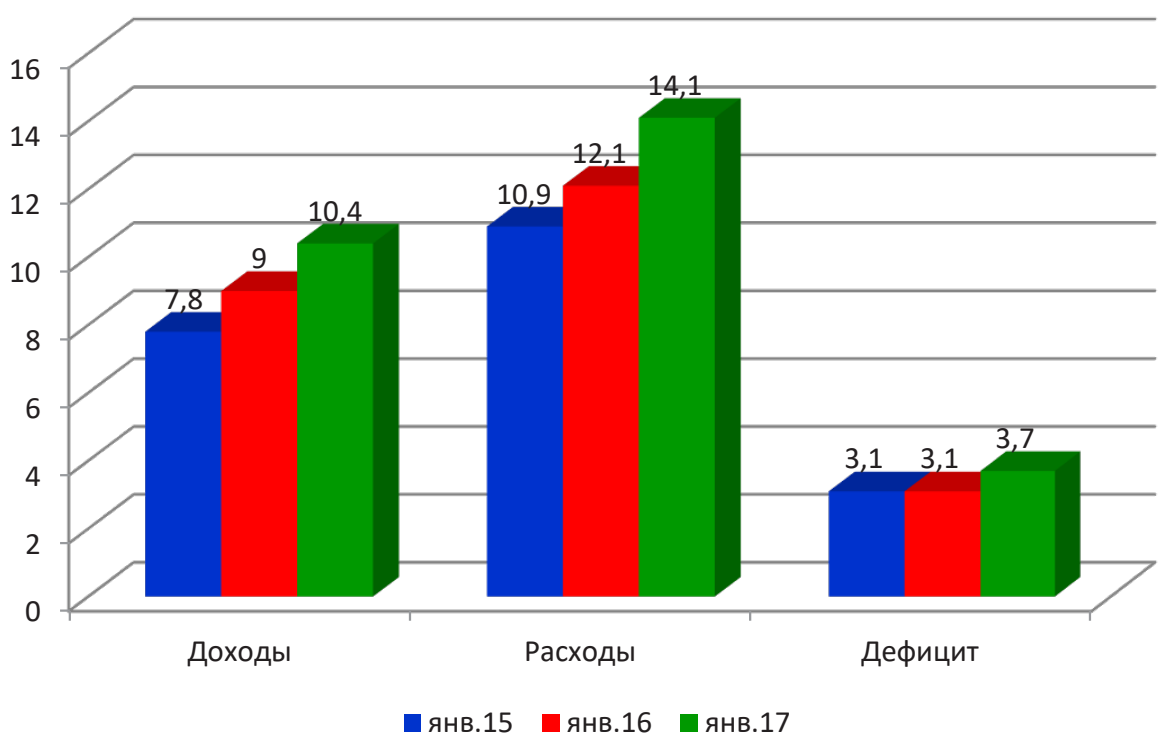

Рисунок 2. Государственный бюджет Индии, млн. индийских рупий (IND)

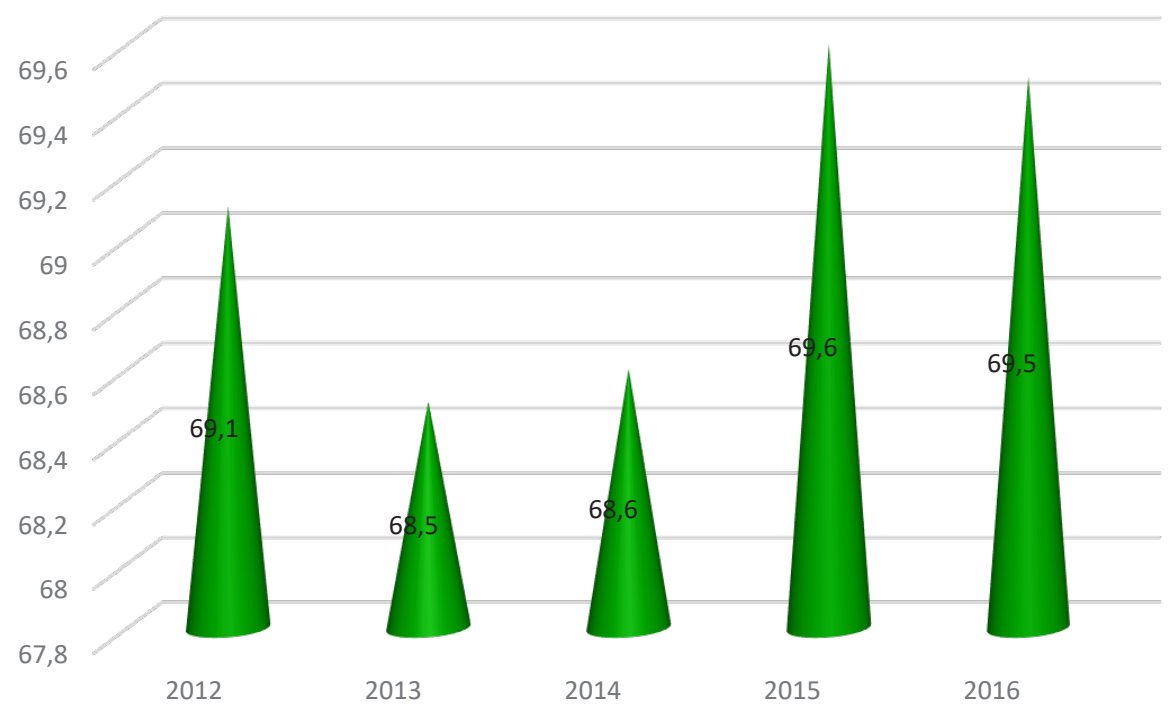

Рисунок 3. Уровень государственного долга Индии, \% от ВВП

Одной из главных особенностей государственного бюджета страны 2017-2018 года является уменьшение величины налога с $30 \%$ до 25\% на малый и средний бизнес Индии, что является основным видом предпринимательской деятельности. Особенно ощутимо было снижение налогов с $10 \%$ до $5 \%$. для микропредприятий, что значительно повлияло на финансово-хозяйственную деятельность предприятия. В связи с тем, что в стране значительный теневой денежный оборот, который составляет $20 \%$ в структуре ВВП были ограничены наличные формы расче- тов населения, а сокращение теневого оборота денег стало одной из приоритетных задач государственного бюджета страны [1].

Несмотря на довольно сложные условия, замедление экономического роста и сокращения зарубежных инвестиций государство активно проводит реформы в финансовом секторе, вследствие чего в долгосрочной перспективе стремиться достичь положительного прогноза развития экономики в долгосрочной перспективе. 


\section{Библиографический список}

1. Брагина Е.А. Индия: бюджет 2017/18 после денежной реформы: официальный сайт [Электронный ресурс]. URL: https://www.imemo.ru/index/ (дата обращения: 22.10.2019).

2. Индия: экономика. Сведения об экономике Индии: официальный сайт [Электронный ресурc]. URL: https:// www.world-globe.ru/countries/india/ (дата обращения: 28.10.2019).

3. Экономика Индии. Основные черты индийской экономики: официальный сайт [Электронный ресурс]. URL: https://www.ereport.ru/articles/ (дата обращения: 21.10.2019).

4. Trading economics. Государственный бюджет Индии: официальный сайт [Электронный ресурс]. URL: https:// tradingeconomics.com/india/ (дата обращения: 15.10.2019).

5. World Development Indicators/ The World Bank: официальный сайт [Электронный ресурс]. URL: http://www. wdi.worldbank.org/table/3.1 World Development Indicators: Rural environment and land use/ (дата обращения: 18.10.2019). 